\title{
Sensorial descriptors for vegetarian pigeon pea hamburger patties according to a focus group
}

\author{
Mora, E. ${ }^{1}$ \& Andrés, C. ${ }^{2}$ \\ 1. Food Technology Research Center (CITA); UCR, San Pedro de Montes de Oca, San José, Costa Rica; eliana.mora@ucr.ac.cr \\ 2. Agroindustry, UNED, Mercedes de Montes de Oca, San José, Costa Rica; candres@uned.ac.cr
}

Received 28-V-2014 • Corrected 24-VII-2014 • Accepted 16-X-2014

\begin{abstract}
Pigeon Pea is a legume that has become an alternative food security crop, associated with improvement of the soil, fodder, green manure and the protection of hidric basins. It is rich in vitamins and proteins and considered nutritious for animals and humans. Four pilot plant tests with Costa Rican beans were done to produce an acceptable formulation of the hamburger patty. We preliminarily found that $15 \%$ of texturized soy, less than $1 \%$ of salt and $2 \%$ of Binder 2.0 were enough to create an acceptable patty for the consumer. Afterwards, a focus group of 12 people found that: a) the product belongs in four trends: good taste, ecology friendly, convenient and multipurpose; b) the target market can be children as well as adults or people with special needs (cholesterol, high blood pressure, diabetes); c) the sensorial descriptors were: healthy, non artificial flavors, with non transgenic soy, with spices (like garlic, onion, basil and rosemary), biodegradable packaging material, transparent lid, and red and yellow or green and orange packaging material; d) can be sold in macrobiotics shops, supermarkets, restaurants and school cafeterias; e) presentation can be 4 to 12 units with flavors like asparagus, mixed vegetables, palmetto and spinach. All participants reported good flavor, intermediate texture (rejected by most), and good color and appearance (cooked and frozen). With additional study, the product can be sold commercially.
\end{abstract}

Key words: Pigeon pea; focus group; sensorial descriptors; vegetarian hamburger patties; healthy.
RESUMEN: El gandul es una leguminosa que se ha convertido en un cultivo alternativo para la seguridad alimentaria, asociada con el mejoramiento del suelo, forraje, abono verde y protección de cuencas hidrográficas. Es rica en vitaminas y proteínas y es considerada nutritiva para animales y humanos. Cuatro pruebas de planta piloto con gandul de Costa Rica se realizaron para producir la mejor formulación de la torta vegetariana para hamburguesa. Preliminarmente encontramos que un $15 \%$ de soya texturizada, menos del $1 \%$ de sal y $2 \%$ de alginato de Binder 2.0 fueron suficientes para producir una fórmula aceptable para el consumidor. Posteriormente, en un grupo focal con 12 personas se encontró que a) se ubicó al producto en las siguientes tendencias: agradable al paladar, ecológico, de conveniencia y multipropósito; b) el público meta puede ser tanto niños como adultos, así como personas con dietas especiales (hipertensión, colesterol o diabetes); c) Los descriptores sensoriales fueron los siguientes: beneficioso para la salud, sin saborizantes artificiales, con soya orgánica no transgénica, con especies (como ajo, cebolla, albahaca y romero), empaque biodegradable, con tapa transparente y de colores rojo y amarillo o verde y naranja; d) Puede comercializarse en macrobióticas, supermercados, restaurantes y sodas escolares; e) su presentación puede ser en paquetes de 4 hasta 12 unidades y puede ser de diferentes sabores como: espárragos, vegetales mixtos, palmito, espinaca. Todos los participantes reportaron un sabor agradable, textura intermedia (rechazada por la mayoría), color y apariencia muy agradables (tanto congeladas como cocinadas). Con estudios adicionales, el producto puede ser comercializado.

Palabras clave: Gandul; grupo focal; descriptores sensoriales; tortas vegetarianas; saludable.
Food security or the hidden hunger is one of the main issues in Food Science these days since climate change and food scarcity are quickly becoming more relevant. Thus, a pigeon pea project was implemented by an interdisciplinary group of researchers at UNED (Costa Rican Distance Education University) in association with ICE
(Costa Rican Electricity Institute) in 2010. The main objective of this project was to implement integral farms in different parts of the Peñas Blancas River and San Carlos, which would provide the following benefits to the owners: food security, addition of nutrients into the ground, protection of hidric basins, fodder, green compost and 
the possibility of developing new products for human consumption. In brief, this project can be beneficial and highly useful for the university and the farmers.

The aim of this project is to develop another new product besides the ones that have already been created with pigeon pea as their main ingredient: a hummus type dip and a legume salad (Andrés, 2013; Andrés, Amerling \& Saravia, 2013). The acceptance of these products was very relevant, which is why the curiosity about the legume increased among the researchers involved and a vegetarian hamburger patty was developed. The reason for choosing this product was that it is very innovative and can compete with soy and other vegetables' hamburger patties in the market.

Pigeon pea (Cajanus cajan) is a legume native to Asia and cultivated currently in Costa Rica. Its different varieties, which are used worldwide as the main ingredient of delicious products and fodder, have many properties. One is a high nutritional value, for instance the important amount of vitamins $A$ and $C$ and protein (Liberterre, n.d). Another is the potential of the plantations to protect the environment which includes water basins and production of organic fertilizer and the other is the ability to fix nitrogen into the soil and therefore, make it more fertile (Aroca, Izaguirre \& Zelaya, 2008). Different tests and observations done by the farmers have shown that five varieties were considered the most fertile and resistant to inclement wheather: Catie, Enana, Sabalito, Folk and Panama (Céspedes, 2012, pers. comm.). This evidence suggests pigeon pea is a plantation that has adapted itself to Costa Rican ground and can be used by farmers.

The five varieties of pigeon pea mentioned above were analyzed based on their color and taste to determine the variety that was going to be used for the patty. Catie is black, Enana is yellow-orange, Sabalito is beige-brown, Folk is,beige and Panama is beige with black dots. Since the aim of this research was to simulate a chicken product, whose color is beige, the Folk variety was chosen to develop meatless vegetarian hamburger patties. In conclusion, this variety was the most adequate to make the hamburger patties.

The most important tendencies in which the consumption of food fit are pleasure, convenience and health and depending on the category of the product, one is more important than the other (Alpizar, 2013). As for vegetarian burgers, the most important tendency is health since the consumption of meat needs to be reduced and replaced by more plant proteins in order to achieve a better diet and sustainability (Boer, Schösler \& Aiking, 2014). This is why this research wants to offer a healthier option for the consumer in a delicious product.
A wide variety of vegetarian burgers have been developed with different trade marks (Amy's Kitchen, Boca Burgers, Sunshine Burgers) and the selection of ingredients used was large, but pigeon pea wasn't among them. Also, a study developed vegetarian hamburger patties but didn't use pigeon pea (Deliza, Saldivar, Germani, Benassi \& Cabral, 2002). Based on the presentations and different raw materials observed in these products, a pigeon pea patty was designed. In brief, vegetarian hamburger patties are products that already have their niche in the market, but pigeon pea patties are still not available, which is what justifies this research.

To determine the formulation of the hamburger patty, texture was a main concern since it was hard to develop a meatless product that could look like the regular hamburger patty. Texture is a physical property of foods that defines their quality and their sensorial acceptance besides defining the bite (Horst-Dieter Tscheuschner, 1998). Since myosin is the binding agent in meat, an ingredient that simulated this characteristic was needed. This ingredient was BDF (Binder 1.0), a mixture of additives used as texturizers with a gelificante power. These additives are sodium alginate, calcium sulfate, pentasodium tripolyphosphate, tetrasodium pyrophosphate (BDF Natural Ingredients, 2009).

The technique called focus group was used to determine the products acceptance. This method allows consumers' perceptions, ideas and experiences to be discussed (Đorđević, Gorton \& Stojanović, 2008), generating results that guide the companies about the possible success of their product and the focus it should have. Another study done with pigeon pea showed also useful results through a focus group (Andrés, 2013). In brief, a focus group is a key part of the development of a new product and needs to be performed in order to achieve valid results.

In conclusion, the development of this product includes different variables that help create a through rough investigation that can lead to a good proposal to be used by small companies, which are part of the goals of the project.

The objectives of this study are three. First develop the best formula for hamburger patties made from pigeon pea as their main ingredient. Second, determine the acceptance consumers have about the patty through a focus group. And third, conclude about the possibility of launching the product to the market. In order to achieve these objectives an extensive literature review was done to obtain as much information as possible about the production of hamburger patties and the market trends. After that, pilot plant tests were done to determine which 
formulation was best to be evaluated by consumers in a focus group. Finally, conclusions and recommendations were drawn in order to improve the quality and acceptance of this product.

The application of focus groups can help not only in explaining consumer behavior, but also in designing more effective nutritional education rules and products that satisfy consumer needs and expectations (Barrios, Bayarri, Carbonell, Izquierdo \& Costell, 2008).

\section{METHODS}

Preliminary tests. The steps that were taken to develop this new product were the ones pointed out by Alpizar (2013) which are: a) find out the tendencies and regulations related to hamburger patties and that can apply to this research; b) plan the development; $c$ ) define raw materials, packaging materials and formulation; $d$ ) obtain results; e) verify that our product complies with the regulations and f) validate our process. To sum up, the development of a product is like the formulation of a project and it needs to comply with a series of steps.

Selection of batches and analysis units (experimental design). In order to perform the preliminary tests four batches manufactured in four different days, each bath had an average of 20 units. In order to guarantee the aleatority of the results, 1 unit from each batch was selected applying a random simple method. Therefore, this design can be considered a $4 \times 1$ factorial design. Each sample was evaluated regarding flavor, appearance (raw and cooked), texture and harness.

Manufacturing of the batches. The batches were similarly done except for the flavor. In Appendix 1 a flow diagram of the process is explained. In the first one, the black variety of pigeon pea was used (Catie) and meat artificial flavor. This is why in the second and third test, the beige variety of pigeon pea was used (folk) and chicken artificial flavor. For the fourth test, less water and vegetal fiber were used which led to obtain a much more satisfying formulation. In brief, a 15\% of soy protein, less than $1 \%$ of salt and $2 \%$ of alginate were enough to develop an acceptable hamburger patty for the consumers.

Focus group. After determining the correct formulation for the hamburger patties, an only session of focus group was organized with 12 consumers who were selected regarding their preference on vegetarian food or innovative products. There were 4 men and 10 women.

Several steps were taken to make the focus group happen. First, when the participants arrived, they were welcomed and explained what a focus group is, how it's used around the world and its mechanism. The session was recorded and there was a moderator who kept track of what the participants said and had a guidance to make sure the exercise was as fluent as possible. Second, a drawing in which the consumers had to determine their ideal hamburger and patty was used. Meanwhile, samples of the hamburgers that had already been prepared were brought into the table next to the participants to be served at the end. The hamburgers had tomato, lettuce, bread, tomato sauce and mayonnaise. Participants didn't analyze a raw patty, only cooked.

Last, the current tendency in which the product fits was discussed. Consumers could choose between health, convenience, prize and flavor or they could put them in order. To wrap the session up, the samples of the product were being served when the participants gave their opinions on what they thought about it and gave suggestions on the appearance, flavor, odor and texture.

\section{RESULTS}

Preliminary tests. Four pilot plant tests were done to define the best formulation for this product. For the first test black pigeon pea and artificial meat flavor were used and it was not accepted due to appearance and taste. The use of this variety was clearly not helpful to simulate the color of a hamburger patty. Also, the flavor and texture of the product did not fit the idea of the prototype. The second and third tests were made with the folk variety of pigeon pea (beige) and artificial chicken flavor. This time, more satisfying results as for color and flavor were obtained, but the texture was still an issue. This is why, in the forth test, less water was used and the consistency improved notoriously. This is the formulation that was used to be evaluated in the focus group which had a $15 \%$ of texturized soy, less than $1 \%$ of salt and $2 \%$ of Binder 2.0 trade mark.

Focus group. The results of the focus group were the following:

a) The trends in which the product was located were: good taste, ecological, convenience and healthy.

b) The target market of this product could be adults and children, with two different presentations and a third target that could be sensitive people (treating it as a functional product).

c) As for ingredients and presentation, panelists defined the product with the following sensorial descriptors: healthy, non artificial flavors, with organic non transgenic soy, with spices like garlic, onion, 
basil and Rosemary; biodegradable red and yellow or green and orange packaging material, with a transparent lid.

d) For its commercialization macrobiotics, supermarkets, restaurants and school cafeterias were recommended.

e) The flavors suggested by the panelists were: asparagus, mixed vegetables, palmetto, and spinach.

This analysis generated positive results since consumers accepted the product in a general way, only requesting better texture and different ingredients.

\section{DISCUSSION}

In this study, the percentage of soy required for the hamburger patty was $15 \%$. By contrast, other investigations such as Torres (2011) have shown a $74 \%$ is necessary when soy is the main ingredient. The amount of fiber of pigeon pea could be an explanation for these results. The versatility of pigeon pea shows how this legume can contribute to Food Security, due to its ability to substitute other plants that are not always going to be available due to climate change or location.

Another important feature mentioned by the consumers was that the soy required needed to be organic or non transgenic, which coincides with the goals of this project (to develop organic and natural products). This preference has also been studied by two other authors. First, Rodríguez-Estrena and Sayadi (n.d.) since consumers expressed their predilection for chemical free and non-harmful to the environment products. Second, Di Monaco, Torrieri and Masi (2007) whom decided to investigate through three focus groups whether product label information "produced with organic ingredients" and "stabilization technology" affects consumer acceptability of vegetable soups. The results demonstrated that if consumers were informed that soup is prepared with organic ingredients, they would improve their acceptability scores, whatever the soup type.

As for texture, egg is normally used in homemade hamburger patties, but in an industrial level, the usage of Binder 2.0, which doesn't affect the products' taste, was recommended by the manufacturers. This generated a pleasant taste and a good texture, although not enough to completely satisfy the consumers. To be able to achieve a better texture, the amount of water in the formulation still needs to be subtracted and tested again. Binder 2.0 itself was good enough for the hamburger patty, but the problem found was the flavor.
The focus group results and sensorial descriptors help us understand what consumers are looking for in our product since the reason why a product is launched to the market is the people that will buy it. Except for its texture, the product had a general acceptance among the consumers.

This experiment placed the vegetarian hamburger patties in four tendencies in the market. One of them was taste, which means it needs to taste good for them to buy it. Similar studies have shown the same results, for instance, Asioli et al. (2014) mention how taste and odor are the most important characteristics in choosing a product and since the consumers of the focus group assessed this feature positively, it means its possibility of acceptance will be high. Another trend was health. The fact of being low in fat and organic had an effect in the acceptance of the product and the trend in which was located (healthy), which seemed very important for consumers. Alpízar (2013) states how the product, which provides a better prevention for health, is the one that has highest probabilities of success.

The third trend in which the product was located (convenience) represents what consumers are looking for these days (something easy and fast to cook). Nevertheless, this trend needs to be hand in hand with the fourth in which it was placed (ecological). Being convenient doesn't have to mean it'll have a packaging material that generates too much waste; on the contrary, it needs to be biodegradable. In brief, the four tendencies of the vegetarian hamburger patties are key to its industrial development, production and launching to the market.

The ingredients used in this product did not include spices, only salt, but the fact that this factor was important to the consumers that participated in the focus group and that other studies have recommended (Andrés, 2013), means more tests need to be done to include other spices that can add better flavor to the product. Even when flavor was accepted, needless to say it could be improved.

A study about ginseng products revealed consumers' knowledge and insights of ginseng and its health effects (Chung, Hong, Kim, Cho, Moskowitz \& Lee, 2011). This coincides with the findings of this article, since consumers were very aware of pigeon pea's health benefits and considered making new products from this legume was beneficial and had great potential, which this article also found.

The influence of attitudes, beliefs and opinions on food choice and purchase is especially important in the acceptance of some types of foods (organic or ecological, 
genetically modified or functional) that are presented to the consumer as a possible alternative to the conventional foods (Barrios et al., 2008).

In a study about low fat cheese it was found that significant changes in flavor and texture are needed for a low-fat Cheddar cheese to have widespread consumer appeal (Childs \& Drake, 2009). This applies to this study regarding the sensorial descriptors generated by consumers which demanded more flavor in the product. A normal hamburger patty has a lot more fat than a vegetarian one, for example a normal red meat hamburger patty has $13,7 \%$ of fat, whereas a soy patty has only $2,6 \%$, which can be similar to a pigeon pea one, although it still needs to be analyzed (Torres, 2011). This difference also affects the flavor of the product and it is something that needs to be improved.

The most important aspects that need to be considered for the hamburger patties in order for their launching to the market to be successful are four: types of ingredients, percentages in the formulation, texture and variety of flavors. The types of ingredients used in the formulation are crucial since a pigeon pea black variety was not accepted, but a beige one (the folk variety). The Sabalito or Panama varieties are also recommended to be tested since they are beige. The percentages used in the formulation are important since the best results were obtained when $2 \%$ of Binder 2.0, $15 \%$ of texturized soy and less than $1 \%$ of salt were used. The texture of the product needs to be improved through another pilot plant test, using less water and more vegetable fiber. This is crucial for the success of the product in the market. And lastly, a wider range of flavors was recommended, not only chicken, but they need to be natural instead of artificial. Based on these outcomes, there is potential for launching the product to the market and succeeding in it.

\section{REFERENCES}

Alpizar, E. (2013). Seminario de desarrollo de productos I: guía de estudio digital. San José, Costa Rica: EUNED.

Andrés, C. (2013). Determinación de los descriptores sensoriales de un dip tipo hummus a base de Gandul (Cajanus cajan) mediante dos mini grupos focales. Cuadernos de investigación UNED, 5(2), 307-317.
Andrés, C; Amerling, C., \& Saravia, K. (2013). Prueba sensorial de grado de satisfacción para una ensalada y un dip tipo hummus elaborados a base de gandul (Cajanus cajan (L.Millsp.). Repertorio Científíco UNED, in press.

Aroca, D., Izaguirre, J., \& Zelaya, F. (2008). Identificación, demarcación y manejo de zonas de recarga hídrica en la Subcuenca Aguas Calientes. FOCUENAS II. Somoto, San Lucas. Retrieved from http://scholar.googleusercontent.com/scholar?q=cache:UOcVz-6o0-oJ:scholar.google.com

Asioli, D., Canavari, M., Pignatti, E., Obermowe, T., Sidali, K., Vogt, C., \& Spiller, A. (2014). Sensory experiences and expectations of italian and german organic consumers. Journal of International Food and Agribusiness, 26(1), 13-27. Retrieved from http://www.tandfonline.com/doi/abs/1 0.1080/08974438.2012.755718

Barrios, E., Bayarri, S., Carbonell, I., Izquierdo, I., \& Costell, E. (2008). Consumer attitudes and opinions toward functional foods: a focus group study. Journal of Sensory Studies, 23, 514-525. Retrieved from http://onlinelibrary. wiley.com/doi/10.1111/j.1745-459X.2008.00169.x/ abstract

BDF Natural Ingredients. (2009). Binder 1.0. Technical description. Provided by supplier.

Boer, J., Schösler, H., \& Aiking, H. (2014). "Meatless days" or "less but better"? Exploring strategies to adapt Western meat consumption to health and sustainability challenges. Appetite, 76, 120-128. Retrieved from http://www.sciencedirect.com/science/article/pii/S0195666314000907

Childs, J \& Drake, M. (2009). Consumer perception of fat reduction in cheese. Journal of Sensory Studies. 24, 902921. Retrieved from http://onlinelibrary.wiley.com/ doi/10.1111/j.1745-459X.2009.00243.x/abstract

Chung, H., Hong, H., Kim, K., Cho, C., Moskowitz, H., \& Lee, S. (2011). Consumer attitudes and expectations of ginseng food products assessed by focus groups and conjoint analysis. Journal of Sensory Studies, 26, 346357. Retrieved from http://onlinelibrary.wiley.com/ doi/10.1111/j.1745-459X.2011.00350.x/references

Deliza, R., Saldivar, S., Germani, R., Benassi, V., \& Cabral, I. (2002). The effects of colored textured soybean protein (tsp) on sensory and physical attributes of ground beef patties. Journal of sensory studies, 17, 121-132. Retrieved from http://onlinelibrary.wiley.com/doi/10.1111/j.1745459X.2002.tb00337.x/abstract

Di Monaco, R., Cavella, S., Torrieri, E., \& Masi, P. (2007). Consumer acceptability of vegetable soups. Journal of Sensory Studies, 22, 81-98. Retrieved from http://onlinelibrary. wiley.com/doi/10.1111/j.1745-459X.2007.00097.x/ abstract. 
Đorđević, J., Gorton, M., \& Stojanović, Z. (2008). Food consumer science. Theories, methods and application to the Western Balkans. Retrieved from http://www.general-ebooks. com/book/75616917-food-consumer-science

Horst-Dieter, T. (1998). Fundamentos de Tecnología de los Alimentos. Acribia, Zaragoza.

Liberterre. (n.d.). Gandul: clasificación botánica. Retrieved from http://www.liberterre.fr/gaiagnostic/semillas/gandul. html
Rodriguez-Estrena, M., \& Sayadi, S. (n.d). La importancia del atributo medioambiente en la elección de productos agroalimentarios: el caso de los alimentos transgénicos. Retrieved from http://www.uibcongres.org/imgdb/archivo_dpo4465.pdf

Torres, A. (2011). Tecnificación del proceso artesanal de la carne de soya a partir de la torta (Okara) proveniente de la leche de soya. Tesis de grado. Escuela Superior politécnica del Litoral. Retrieved from http://www.dspace.espol.edu. ec/handle/123456789/16922.

APPENDIX 1

Flow diagram for vegetarian hamburger patties made from pigeon pea

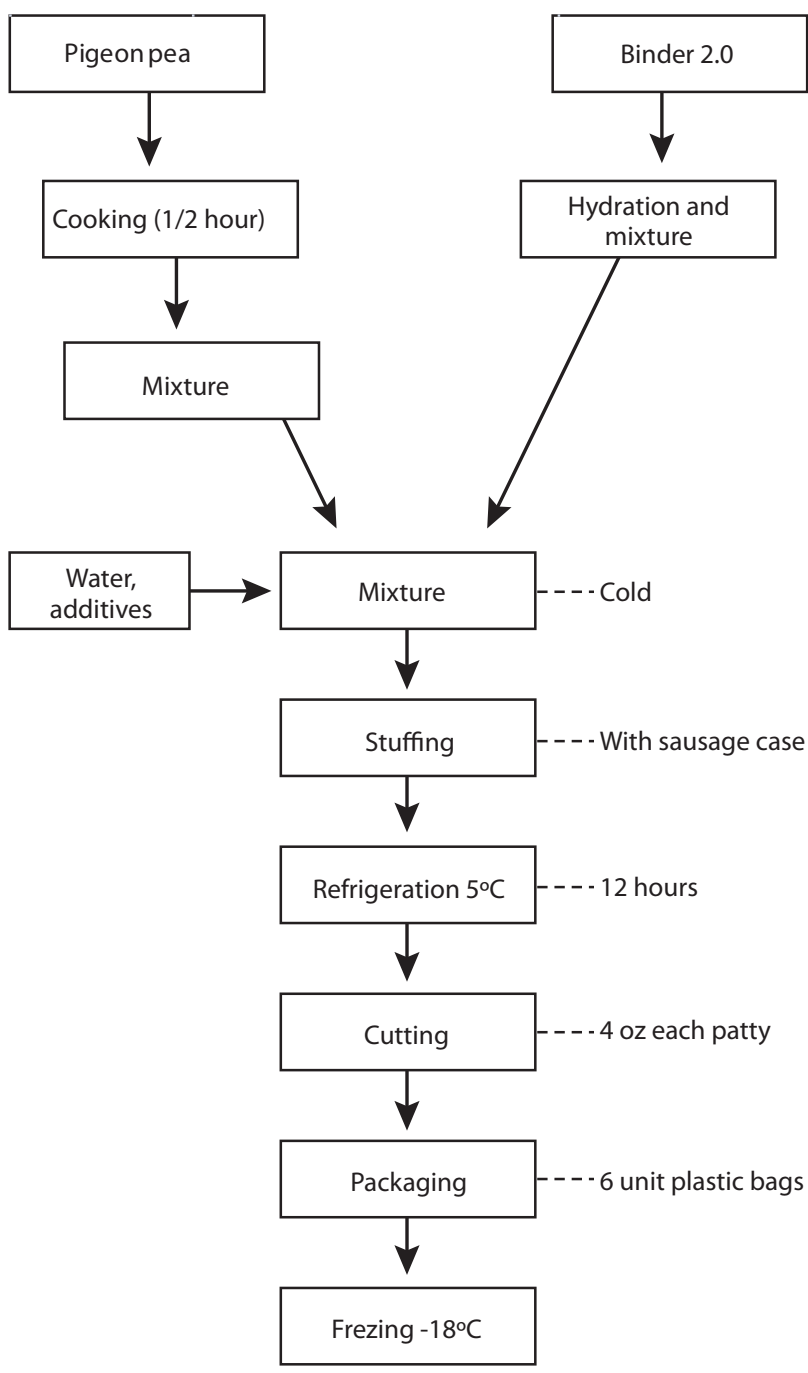

